chodzenie. Dlatego też najlepiej przyjąć ostateczne powstanie tablicy narodów w okresie niewoli babilońskiej, kiedy to Żydzi lepiej zrozumieć mogli własne tradycje narodowo-religijne, porównując je $\mathrm{z}$ tradycjami innych narodów. ${ }^{18}$ Tablica narodów ma $\mathrm{z}$ pewnością długą historię powstawania, która dotychczas nie została należycie opracowana. Przypuszcza się jedynie, że początki tablicy narodów sięgają drugiej połowy drugiego tysiąclecia przed Chr. - Kanaan należał wtedy pod względem politycznym do Egiptu (=Kanaan synem Chama) ${ }^{19}$ - a ostateczne „ramy” otrzymała w okresie niewoli babilońskiej.

\title{
4. ZNACZENIE
}

Tablica narodów próbuje wywieść wszystkie narody ziemi od wspólnego przodka, którym jest Noe (por. szczególnie w. 5 i 32; por. też $\mathrm{Dz}$ 17,26). Noe zawdzięcza owo rozmnożenie specjalnemu błogosławieństwu Bożemu (por. Rdz 9,1). Dlatego też wszystkie narody ziemi stoją niejako $\mathrm{w}$ promieniach owego błogosławienstwa ${ }^{20}$ Izrael zaś został nie tylko wybrany z tej wielkiej palety narodów, ale ponadto ma wobec nich zadanie zbawcze.

Wiedeń

KS. NORBERT' MENDECKI

\section{Ks. Andrzej Kowalczyk}

\section{DLACZEGO MAREK NAPISAŁ DRUGA EWANGELIĘ?}

Dyskusja wokół kolejności powstania Ewangelii synoptycznych nie jest bynajmniej zakończona, jakkolwiek trwa już ponad sto lat. Kościół w starożytności i w wiekach późniejszych aż do niemal końca XVIII w. przyjmował, że pierwszą Ewangelią była Ewangelia Mateusza, a drugą Marka. Na taką kolejność wskazuje większość bardzo starych świadectw o powstaniu Ewangelii, mianowicie: św. Irene-

18 J. N e 1 i s, dz. cyt., 1853.

${ }^{10} \mathrm{H}$. D o n n e r, dz. cyt., 53-54, por. też przypis 12 .

${ }^{20} \mathrm{C}$. W e s t e r m a n n, dz. cyt., 704-706. 
usza (r. 140-202), Orygenesa (r. 185-255) i św. Hieronima (r. 349420). Pierwszym uczonym starożytności, który zajął się problemem różnic w Ewangeliach i ich wzajemną zależnością był św. Augustyn (r. 353-430). Biorąc pod uwagę podobieństwa jakie spotykamy w Ewangeliach synoptycznych doszedł on do wniosku, że pierwszą jest Ewangelia Mateusza, Marek skrócił Ewangelię Mateusza, a Lukasz korzystał z obu Ewangelii. Trzeba dodać, że szczegółowa analiza literacka Ewangelii synoptycznych w dużej mierze potwierdza hipotezę św. Augustyna. Np. znajdujemy niekiedy w nich w tych samych miejscach identyczne bardzo rzadkie słowa, które najłatwiej wyjaśnić właśnie zależnością literacką.

Przyjmowana tradycyjnie opinia o pierwszeństwie Mateusza została po raz pierwszy zakwestionowana przez G. Ch. Storra w roku 1794, a w pierwszej połowie dwudziestego wieku stała się dla wielu biblistów niepodważalnym pewnikiem.

Zobaczmy, jak wyobraża sobie powstanie Ewangelii Marka R. Bultmann ${ }^{1}$, którego opinie wywarły wielki wpływ na współczesną biblistykę. Według niego Ewangelia Marka jest owocem długiego procesu dokonywującego się $\mathrm{w}$ lonie pierwotnej gminy. Po śmierci Jezusa, gmina żyła nadal pod wrażeniem Jego działalności i nauki, na zebraniach przypominano sobie słowa Jezusa i różne wydarzenia z Jego życia. W związku z tym spontanicznie powstawały krótkie utwory przekazywane ustnie, należące do różnych rodzajów literackich, które można uszeregować w dwóch grupach: tradycji słów i tradycji faktów. Do pierwszej grupy Bultmann zalicza: apoftegmaty, czyli krótkie opowiadania zawierające sentencję Jezusa, oraz sentencje niezależne od opowiadania. Do tradycji faktów zalicza on: opisy cudów, opisy historyczne i legendy. Niemal każde z tych rodzajów literackich dzieli jeszcze na podgrupy. Np. apoftegmaty dzieli na kontrowersje, dyskusje szkolne i apoftegmaty biograficzne; sentencje - na: aforyzmy sapiencjalne, prorockie i apokaliptyczne, reguły prawne itd. Według Bultmanna te krótkie utwory niewiele miały wspólnego z Jezusem historycznym, były one wyrazem wiary gminy i powstawały poza kontrolą naocznych świadków. Na podstawie tych utworów nie możemy powiedzieć o Jezusie, Jego życiu i nauce, nic pewnego. Cechą charakterystyczną powstającej w łonie gminy tradycji słów i faktów była jej anonimowość, tendencja do upiększania, teatralność, zamiana materiału narracyjnego na mowę bezpośrednią, powtarzanie, zainteresowanie cudownymi wydarzeniami, natomiast pomijanie chronologii. Te małe utwory przekazywane ustnie zmieniały swoją formę, a następnie krzyżowały się ze sobą, powstawały różne wersje tego samego apoftegmatu, tego samego opowia-

${ }^{1}$ R. B u 1 t m a n n, Die Formgeschichte des Evangeliums, Göttingen, 1921. 
dania o cudzie itd. Odmienne środowisko i czas, w jakim powstawał dany utwór, wyciskał piętno na jego języku. Tradycja ustna rosła jak żywy organizm. Z czasem zaczęły pojawiać się te małe utwory również na piśmie, powstawały nawet całe ich zbiory. Ale i one ulegały zmianom. W całym bogactwie ustnego, a także przedewangelicznego pisemnego przekazu Bultmann wyróżnia dwa sposoby przedstawiania Jezusa, dwie zasadnicze tradycje teologiczne: palestyńską i hellenistyczną. Ta druga, związana z gminami o kulturze greckiej, była rozszerzana przez Pawła i Marka. Cechowała ją mitologizacja osoby Jezusa, albo innymi słowami - położenie nacisku na Jego bóstwo oraz wartość zbawczą Jego śmierci i zmartwychwstania. Według Bultmanna tradycja ustna na drodze swojego rozwoju dążyła w sposób naturalny do ustalenia na piśmie. Tego dzieła - zredagowania Ewangelii pisanej - dokonał właśnie jako pierwszy Marek. Nie był on prawdziwym autorem Ewangelii. Jego praca polegała na zebraniu istniejących już małych form literackich oraz ich grup w jedną księgę, połączenia ich przy pomocy nieznacznych tylko retuszów w jedno spójne opowiadanie. Marek - twierdzi Bultmann - korzystał $\mathrm{w}$ swojej pracy redakcyjnej $\mathrm{z}$ obydwu tradycji teologicznych: palestyńskiej i hellenistycznej.

W tej koncepcji tradycji ustnej i powstania Ewangelii Marka jest jednak dużo elementów wątpliwych, a nawet niemożliwych do przyjęcia. Pierwszym $z$ nich to pozbawienie tradycji ustnej wartości historycznej. Nie wiadomo dlaczego Bultmann nie zakorzenia tej tradycji w nauczaniu Jezusa i w gminie przedpaschalnej. Również w sposób apriorystyczny wyłącza on tradycje spod kontroli naocznych świadków życia Jezusa, a zwłaszcza apostołów, którzy byli specjalnie przez Jezusa przygotowywani do głoszenia Ewangelii. Twierdzenie o spontanicznej i anonimowej twórczości gminy opiera Bultmann na fakcie różnic w Ewangeliach, ale różnice te można tłumaczyć także w inny sposób. W każdym bądź razie to nie jest wcale takie pewne, że odbiorcy tradycji ustnej traktowali ją w sposób bezkrytyczny, a odpowiedzialni za jej przekazywanie byli obojętni na jej treść. Innym błędnym twierdzeniem Bultmanna jest wyróżnianie dwóch tradycji: palestyńskiej i hellenistycznej. Dane literackie nie wskazują na tego rodzaju dualizm. Wreszcie należy podkreślić, że Bultmannowska wizja rozwoju tradycji w sposób linearny, w jednym kierunku, którego ukoronowaniem jest Ewangelia pisana, nie jest zgodna z wynikami refleksji nad tradycją ustną współczesnych uczonych, jak np. Wernera Kelbera. ${ }^{2}$ Dzisiaj raczej uważa się, że utwory przekazu ustnego nie tylko mogły się rozrastać, ale również mogły być skracane. Poza tym należy stwierdzić, że określone przez Bultmanna rodzaje literackie w ramach tradycji faktów i tradycji

${ }^{2}$ W. K e l b e r, Tradition orale et écriture, Paris 1991. 
słów są czysto hipotetyczne. Poszukiwanie przez Bultmanna formy oryginalnej małych jednostek przekazu ustnego jest np. wg Kelbera $\mathrm{z}$ góry skazane na niepowodzenie, ponieważ w tradycji ustnej trudno w ogóle mówić o jakiejś ustalonej formie oryginalnej. Właśnie cechą przekazu ustnego jest pewna zmienność formy i treści.

Trzeba przyznać, że za pierwszeństwem Ewangelii Marka przemawiają co najmniej dwa poważne argumenty: że jest ona najkrótszą Ewangelią oraz żè nie posiada dwóch bardzo ważnych fragmentów - ewangelii dziecięctwa obejmującej dwa rozdziały i kazania na górze obejmującego aż trzy rozdziały. Czy jest możliwe - pytają się zwolennicy jej pierwszeństwa aby Marek, znając Ewangelię Mateusza, świadomie opuścił te fragmenty? B. H. Streeter, opowiadając się za istnieniem przed Mateuszem nie tylko Ewangelii Marka, lecz również źródła Q i dwóch innych żródeł, był zdania, że tylko lunatyk mógłby przyjąć takie świadome opuszczenie. ${ }^{3}$ A jeśli Marek nie znał Ewangelii Mateusza - czy jest możliwe, aby w tradycji, z której czerpał, a była to tradycja ta sama, z której czerpał Mateusz, nie było nic na temat dziecięctwa Jezusa ani żadnego większego fragmentu wchodzącego w skład kazania na górze? Zwykle za pierwszeństwem Marka podaje się jeszcze inny argument: Ewangelia Marka jest skoncentrowana na cudach Jezusa, jest najmniej teologicznie rozwiniętą. Np. W Ewangelii Mateusza Piotr wyznaje wiarę w Jezusa-Mesjasza i zarazem Syna Boga żywego $(16,16)$, natomiast w Ewangelii Marka Piotr odpowiada Chrystusowi jedynie: „Ty jesteś Mesjasz" $(8,29)$. A ponadto Marek w tejże samej perykopie nie wspomina nic o obietnicy prymatu Piotra, podczas gdy Mateusz ma na ten temat trzy wiersze. W tym miejscu należy dodać, że Marek nie posiada wielu przypowieści na temat królestwa niebieskiego. Czy nie należało by się spodziewać w drugiej Ewangelii teologii bardziej rozwiniętej niż w pierwszej?

W każdym bądź razie opowiadając się za tradycyjną kolejnością Ewangelii należy wyjaśnić, dlaczego Marek znając Ewangelię Mateusza napisał drugą, o wiele krótszą?

Odpowiedź na to pytanie - broniąc pierwszeństwa Mateusza starają się dać zwolennicy teorii Griesbacha: W. R. Farmer, D. L. Dungan i B. Orchard. Według teorii J. J. Griesbacha opublikowanej w r. 1789 Ewangelia Marka powstała jako skrót istniejących już wcześniej Ewangelii Mateusza i Łukasza - pierwszą była Ewangelia Mateusza. Do takich wniosków doprowadził Griesbacha przede wszystkim fakt istnienia w Mk tzw. konflacji, czyli fơrmuł składających się z dwóch „połówek”, z których jedna występuje u Mt a druga

${ }^{3}$ B.H. S t r e e t e r, The Four Gospels: A Study of Origins, London 1924, s. 158. 
u Łk; por. Mt 8, 16: „Z nastaniem wieczora”; Łk 4, 40: „O zachodzie słońca”; Mk 1,32: „Z nastaniem wieczora, gdy zaszło słońce”.

Teoria Griesbacha miała niegdyś wielkie powodzenie, przyjmowała ją np. szkoła tybingeńska. W latach sześćdziesiątych podjął ją na nowo i rozwinął Farmer. ${ }^{4}$ Jednym $z$ głównych argumentów przeciwko pierwszeństwu Marka jest według niego zgodność Mateusza i Łukasza przeciwko Markowi w materiale Markowym. Skróty w Ewangelii Marka Farmer wyjaśnia tym, że Marek oparł się w kompozycji Ewangelii na kazaniu apostoła Piotra, które zaczyna się właśnie od chrztu Jezusa (por. Dz. Ap.1, 21-22), oraz że chciał on usunąć większość tradycji żydowskiej znajdującej się w dwóch pierwszych Ewangeliach. ${ }^{5}$

D. L. Dungan znajduje jeszcze inny motyw; według niego Marek chciał usunąc sprzeczności, jakie dostrzegał w tych Ewangeliach; np. dwie różne ewangelie dziecięctwa. ${ }^{6}$

Natomiast B. Orchard mocno podkreśla, że Ewangelia Marka właściwie nie miała być trzecią Ewangelią, ale streszczeniem nauczania Piotra, który posługiwał się Ewangeliami: Mateusza i Łukasza; brak u Marka wielu perykop znajdujących się w poprzednich Ewangeliach jest wynikiem opuszczania ich przez Piotra. ${ }^{7}$ Uważa on, że teorie o pierwszeństwie Marka powstały na gruncie szerzących się w dobie Oświecenia uprzedzeń do tradycji Kościoła i w istocie nie opierają sie na przekonywujących dowodach literackich. Orchard, idąc za Griesbachem, uważa, że wyraźnym dowodem korzystania przez Marka z Ewangelii Mateusza i Łukasza jest porządek perykop w tych trzech Ewangeliach: Marek raz jest zgodny z Mateuszem raz z Łukaszem. Dlaczego Piotr posługuje się dwoma Ewangeliami? Dlatego dwoma - wyjaśnia Orchard - aby swoim autorytetem zaświadczyć o prawdziwości Ewangelii Łukaszowej napisanej dla pogan.

Orchard mocno podkreśla, że teoria o pierwsizeństwie Marka nie znajduje oparcia w świadectwach starożytnego Kościoła, natomiast już świadectwo Papiasza mówi o Ewangelii Marka jako odzwierciedleniu katechezy Piotrowej. Papiasz pisze: „Także te sprawy poruszył prezbiter Marek stawszy się tłumaczem Piotra, zapisał wszystko dokładniej cokolw:ak sobie przypomnial, jednak nie po kolei o słowach i czynach Pana. Nie widział bowiem Pana ani nie poszedł za Nim, lecz dopiero później za Piotrem. Ten znów układał swoje

${ }^{4}$ W.R. F a r m e r, The Synoptic Problem, New York 1964.

${ }^{5}$ W.R. F a r m e r, Jesus and the Gospel, Tradition, Scripture and Canon, Philadelphia 1982, 165n.

${ }^{6}$ D.L. D u n g a n, Mark - The Abridgements of Matthew and Luke, w: Jesus and Man's Hope, red. D. H i d i d i a n, t. 1, Pittsburg 1970, 88n.

${ }^{7}$ B. O r c h a r d, Matthew, Luke and Mark, Manchester 1976. 
nauki według potrzeb (słuchaczy), jednak nie w ten sposób, by zamierzał przedłożyć zestaw słów Pana. Dlatego też nie wina Marka w tym, że niektóre rzeczy tak napisał, jak je przechował w pamięci. Cała jego troska była w tym, by z tego, co usłyszał (od Piotra), nic nie opuścił ani przekazał niewiernie". Za teorią Griesbacha jeszcze bardziej wyrażnie przemawia starożytne świadectwo Klemensa Aleksandryjskiego: „Po publicznym głoszeniu słowa przez Piotra w Rzymie i ich przepowiadaniu w duchu Ewangelii, mieli się niektórzy jego słuchacze do Marka zwrócić z prośbą, aby spisał jego naukę, ponieważ już od dawna towarzyszy Piotrowi i ma jego słowa w pamięci. Marek więc spełnił ich prośby i dał im Ewangelię. Gdy Piotr dowiedział się o tym, ani go nie strofował, ani go do tego zachęcal".

Z najstarszych świadectw wynika, że Ewangelia Marka była drugą z kolei - po Ewangelii Mateusza. Tak na temat powstania Ewangelii Mateusza i Marka pisze św. Ireneusz ok r. 202: „Otóż Mateusz dla Hebrajczyków napisał i wydał Ewangelię w ich ojczystym języku, podczas gdy Piotr i Paweł w Rzymie ewangelię opowiadali i zakładali Kościół. Po ich odejściu Marek, uczeń i tłumacz Piotrowy, przekazał nam również na piśmie to, co Piotr głosił”. Według Klemensa Aleksandryjskiego (r. 150-215) najpierw miały powstać te Ewangelie, które posiadają rodowody Jezusa, a więc Mateusza i Łukasza. Ale uczeń Klemensa i jego następca w Szkole Aleksandryjskiej, wielki uczony starożytności chrześcijańskiej - Orygenes (r. 185-255) jest innego zdania. Pisze on: „Na podstawie tradycji dowiedziałem się w sprawie czterech Ewangelii, które jedynie jako niewątpliwe uznaje Kościół Boży, że pierwszą z nich pisał ongi celnik, a potem apostoł Jezusa Chrystusa, Mateusz, że wydał ją dla wiernych pochodzenia żydowskiego, a pisał w języku hebrajskim. Drugą zaś jest Ewangelia według Marka, który ją ułożył według wskazówek Piotra..."

Trzeba jednak powiedzieć, że obrońcy teorii Griesbacha, jakkolwiek mają sporo racji, np. jeśli chodzi o usuwanie tradycji żydowskiej z Ewangelii przeznaczonej dla pogan, nie potrafią wyjaśnić w sposób przekonywujący braku ewangelii dziecięctwa, kazania na górze i wielu przypcwieści o królestwie.

Powodem napisania drugiej Ewangelii mógł być zamiar dostosowania Ewangelii pisanej do wymogów greckich kanonów literackich. Taki wniosek nasuwa się w związku z hipotezą B. Standaerta, ${ }^{8}$ który stara się wykazać, że Ewangelia Marka posiada strukturę zgodną z zasadami retoryki sformułowanymi przez Kwintyliana. Według Kwintyliana mowa powinna dzielić się na pięć części: (1) wprowa-

${ }^{8}$ B. S t a n d a e r t, L'Evangile selon Marc, Composition et genre litteraire. Nijmegen 1984 . 
dzenie; (2) narratio, czyli przedstawienie danych; (3) argumentatio; (4) refutatio, czyli wyciągnięcie wniosków; (5) conclusio. Właśnie pięć takich części widzi Standaert w drugiej Ewangelii. Pierwszych trzynaście wierszy stanowi wprowadzenie. Narratio to część Ewangelii od 1,14 do 6,13. Mamy tutaj najważniejsze tematy, które będą później rozwijane: tożsamość Jezusa i żądanie pojścia za Nim. Zarysowuje się akcja dramatu. Część 6,14-10,52 to narratio. Rozpoczyna się ona od podstawowego pytania: Kim Jezus jest? - i dzieli się na trzy sekcje: sekcję chleba $(6,30-8,21)$, której głównym tematem jest godność Jezusa, sekcję 8,27-9,13 zbudowaną koncentrycznie, której tematem jest obok godności Jezusa także objawienie apostołom ich powołania do naśladowania Jezusa, wreszcie sekcję trzecią 9,30 10,45 poświęconą wymaganiom, jakie Jezus stawia swoim uczniom. Czwarta część 11,1-15,47 czyli działalność Jezusa w Jerozolimie, męka i śmierć zawiera rozwiązanie dramatu. Opowiadanie o zmartwychwstaniu Jezusa w 16,1-8 to epilog dzieła. Standaert uważa, że punktem centralnym Ewangelii Marka jest perykopa o sądzie Heroda o Jezusie $(6,14-16)$, wokół niej koncentrycznie ułożone są inne perykopy. Ponadto uważa on, że także inne części mają strukturę koncentryczną.

Niestety, stwierdzamy, że druga Ewangelia nie odpowiada kanonom Kwintyliana, tak jak to Standaert widzi. Np. dlaczego opowiadanie o działalności Jezusa w Jerozolimie i o męce należy rozumieć jako refutatio, czyli wyciągnięcie wniosków? Trudno też zgodzić się z tezą o budowie koncentrycznej. Jeśli już mamy wskazać punkt centralny Ewangelii, to narzuca się zupełnie inny - mianowicie wyznanie wiary przez Piotra w 8,29 albo przemienienie Jezusa w 9,2-8. Chyba jednak nie wymagania retoryki stały u podstaw tej Ewangelii.

Dotychczasowe próby wyjaśnienia skrótów Markowych nie są więc w pełni udane, niemniej wydaje nam się mimo wszystko, że bezpośrednia zależność literacka Marka od Mateusza jest bardziej prawdopodobna od innych rozwiązań i że należy te próby podejmować $w$ dalszym ciągu. Za pierwszeństwem Mateusza przemawiają bardzo poważne argumenty, nie licząc tych, opartych na starożytnych świadectwach, mianowicie podkreślane przez zwolenników teorii Griesbacha: konflacje w Ewangelii Marka i niezgodność Mateusza z Łukaszem w materiale Markowym. Myślę, że jeszcze raz warto, może nieco $\mathrm{w}$ innym aspekcie, zastanowić się nad usuwaniem przez Marka tekstów Mateuszowych związanych z tradycją żydowską, albo może lepiej - ze środowiskiem żydowskim; oraz przeanalizować usuwanie pewnych Mateuszowych tekstów w związku z potrzebą nowej koncepcji ewangelizacji związanej z nowym adresatem - światem pogańskim. 
Ze świadectw starożytnego Kościoła odnośnie do Ewangelii wynika, że Ewangelia Mateusza napisana była dla Żydów, natomiast Ewangelia Marka dla słuchaczy apostoła Piotra w Rzymie, którymi byli niewątpliwie głównie poganie. Analiza Ewangelii Marka wskazuje na to, że jej adresaci nie znali zwyczajów żydowskich. Np. w związku z polemiką Chrystusa z faryzeuszami na temat obmywania rąk, Marek wyjaśnia: „Faryzeusze bowiem, i w ogóle Żydzi, trzymając się tradycji starszych, nie jedzą, jeśli sobie rąk nie obmyją, rozluźniając pięść. I gdy wrócą z rynku, nie jedzą, dopóki się nie obmyją. Jest jeszcze wiele innych zwyczajów, które przejęli i których przestrzegają, jak obmywanie kubków, dzbanków, naczyń miedzianych" (7,3-4). Takich wyjaśnień Żydzi nie potrzebowali. I rzeczywiście zacytowanych wierszy nie ma w Ewangelii Mateusza w perykopie paralelnej w 15,1-9. Zwroćmy uwagę, że Marek pisze tutaj o Zydach w trzeciej osobie, jako o narodzie słuchaczom obcym. Głoszenie Ewangelii w środowisku pogańskim postawiło problem przystosowania Ewangelii Mateusza do tego środowiska. Pierwsza Ewangelia była zbyt mocno związana $\mathrm{z}$ tematyką żydowską. Znaczne jej fragmenty mogły nie interesować pogan, a nawet ze względu na ich koloryt żydowski mogły ich razić. Do takich fragmentów można by zaliczyć między innymi: genealogię Jezusa, perykopy o stosunku Jezusa do Prawa ST, krytykę pobożności faryzejskiej, mowe przeciwko faryzeuszom i uczonym w Piśmie.

Mateusz na samym początku swojej Ewangelii wykazuje, że Jezus był Żydem i pochodził z rodu Dawida. Pierwsze zdanie jego Ewangelii brzmi: „Rodowód Jezusa Chrystusa, syna Dawida, syna Abrahama". Dla niego i dla jego żydowskiego audytorium była to sprawa zasadnicza: z rodem Dawida łączyły się obietnice mesjańskie. Ale czy genealogia Jezusa mogła interesować Rzymian? Kim dla Rzymian był Abraham albo Dawid? Dlatego Marek nie umieszcza genealogii w swojej Ewangelii. Warto w tym miejscu podkreślić, że Lukasz, który również pisze dla pogan, Abrahama traktuje jedynie jako jedno $\mathrm{z}$ ogniw w genealogii, a całą genealogię doprowadza aż do Adama.

Drugi temat, który z pewnością nie interesował Rzymian w takiej mierze co Zydów, to stosunek Jezusa do Prawa ST. Mateusz poświęca mu wiele miejsca, Prawo ST było dla Żydów Prawem Bożym, drogą zbawienia; uważali oni, że jest ono wieczne. Jezus wypowiadał się na temat Prawa, a zatem należało przedstawić sprawę dokładnie. Przede wszystkim Mateusz uspakaja swoich słuchaczy: Jezus nie zniósł Prawa nawet domaga się większej sprawiedliwości, czyli doskonałości moralnej, od tej, którą reprezentują faryzeusze uważający się za stróżów Prawa. Mateusz zanim przejdzie do redakcji zbioru nowego Prawa w kazaniu na górze, umieszcza słowa 
Jezusa: „Nie sądźcie, że przyszedłem znieść Prawo albo Proroków. Nie przyszedłem znieść, ale wypełnić” (Mt 5,17). Dużo miejsca w kazaniu na górze zajmuje sześć antytez, w których Jezus przeciwstawia starym przepisom nowe zasady postępowania. Zaczynają się one od formuły: „Słyszeliście, że powiedziano przodkom... A Ja wam powiadam" lub podobnej. Czy było konieczne przedstawiać Rzymianom, którzy nie znali Prawa ST, jak Jezus wypowiadał się na temat Prawa? Tym bardziej, że niektóre z jego przepisów ogłaszał jako nie obowiązujące. Nic dziwnego, że Marek opuszcza perykopę o stosunku Jezusa do Prawa ST wraz ze wspomnianymi antytezami. Również Łukasz teksty te opuszcza.

Wreszcie Jezusowa krytyka faryzeuszów i uczonych w Piśmie. W Ewangelii Mateusza mamy oprócz licznych polemik z uczonymi w Piśmie i faryzeuszami długą mowę skierowaną przeciwko nim w rozd. 26. Zawiera ona aż 36 wierszy. Chrystus demaskuje w niej pychę i obłudę faryzeuszów i uczonych w Piśmie używając bardzo ostrych sformułowań: „obłudnicy”, „ślepi wodzowie”, głupi i ślepi”, „plemię żmijowe”. W Ewangelii skierowanej do Żydów tego rodzaju fragment musiał się znaleźć, uczeni w Piśmie i faryzeusze byli bowiem rzeczywistymi przywódcami narodu. Dla przeciętnègo Żyda opinia faryzeuszów o Jezusie była obowiązująca, a przynajminiej bardzo ważna. Niestety, opinia ta była negatywna. Mateusz musiał wyjaśnić swoim słuchaczom, gdzie należy szukać przyczyn tej negatywnej opinii - otóż należy szukać w ich zakłamaniu, w nienawiści do Jezusa, który nie obawiał się odsłonić całej prawdy o nich. Krytyka faryzeuszów i uczonych w Piśmie była potrzebna w przepowiadaniu Ewangelii Żydom, ale nie była już tak samo potrzebną w przepowiadaniu Rzymianom. Nawet więcej, mogła wywołać niepotrzebnie niechęć do Żydów, czego apostołowie sobie z pewnością nie życzyli. O swego rodzaju antysemityzmie w gminie rzymskiej można wnioskować z rozdziału jedenastego Listu św. Pawła do Rzymian. Po cóż było więc rozpisywać się o żydowskich przywódcach i dodawać czerni do ich obrazu? Znowu więc nic dziwnego, że Marek 36 wierszy tej mowy Jezusa redukuje do zaledwie czterech wierszy nie powtarzając ani jednego $\mathrm{z}$ ostrych sformułowań (por. Mk 12,37-40). Należy dodać, że Łuk asz w swojej Ewangelii dla pogan idzie w tym wypadku dokładnie śladami Marka redukując mowę przeciwko uczonym w Piśmie i faryzeuszom do tych samych czterech wierszy (por. Łk 20,45-47).

Wspomnieliśmy o nastrojach antysemickich $\mathrm{w}$ gminie rzymskiej. Otóż niewątpliwie Marek liczy się z tymi nastrojami i dlatego nie włącza do swojej Ewangelii wiele takich sformułowań znajdujących się w Ewangelii Mateusza, które w złym świetle przedstawiają Żydów. Np. w perykopie o nowym żądaniu znaku (Mk 8,10-13/Mt 
16,1-4) Jezus w Mt nazywa Żydów „plemieniem przewrotnym i wiarołomnym”, podczas gdy u Mk mowi jedynie: „Czemu to plemię domaga się znaku, żaden znak nie będzie dany temu plemieniu". W opowiadaniu o cudownym uzdrowieniu epileptyka (Mk 9,1429/Mt 17,14-21) w zdaniu, które u Mt brzmi: „O plemie niewierne i przewrotne!” - Marek opuszcza słowo „przewrotne”. W perykopie o oszczerstwach uczonych w Piśmie ( Mk 3,22-30/Mt 12,22-27) Marek opuszcza między innymi słowa: „Plemię żmijowe! Jakże wy możecie mówić dobrze, skoro źli jesteście? Przecież z obfitości serca mówią usta" (Mt 12,34). Marek opuszcza też najbardziej antyjudaistycznie brzmiący tekst Mateuszowy znajdujący się w opisie procesu Jezusa przed Piłatem (Mk 15,1-17/Mt 27,11-28): „(Piłat) wziął wodę i umył ręce wobec tłumu, mówiąc: «Nie jestem winien krwi tego Sprawiedliwego. To wasza rzecz". A cały lud zawolat: "Krew Jego na nas i na dzieci nasze»" (Mt 27,24-25). Bardzo surowo osądza Jezus swój naród w opowiadaniu Mateuszowym o uzdrowieniu sługi setnika (Mt 8,5-13): „Zaprawdę, powiadam wam: U nikogo w Izraelu nie znalazłem tak wielkiej wiary. Lecz powiadam wam: Wielu przyjdzie ze Wschodu i Zachodu i zasiądą do stołu z Abrahamem, Izaakiem i Jakubem w królestwie niebieskim. A synowie królestwa zostaną wyrzuceni na zewnątrz - w ciemność; tam będzie płacz i zgrzytanie zębów" (Mt 8,10-12). Marek prawdopodobnie nie chce tej negatywnej opinii Jezusa o Żydach rozpowszechniać wśród pogan i dlatego opuszcza całe to opowiadanie.

Trzeba jednak stwierdzić, że zamiar zredukowania w Ewangelii dla pogan tematyki żydowskiej oraz wyeliminowanie $\mathrm{z}$ niej, o ile to możliwe, elementów antyjudaistycznych nie tłumaczy w całości powstania Ewangelii Marka. W drugiej Ewangelii brak jest wielu tekstów, których usunięcie trudno wytłumaczyć taką właśnie racją. A poza tym jest $w$ niej zmieniona kolejność wielu zachowanych perykop Mateuszowych.

Wydaje się, że następnym powodem powstania drugiej Ewangelii była zmiana samej koncepcji przepowiadania. Nowe środowisko środowisko pogan wymagało przepracowania treści kerygmatu. Nie chodzi oczywiście o jakieś nowe prawdy wiary albo usunięcie prawd wiary już głoszonych, ani też o rezygnację $\mathrm{z}$ jakichś zasad etycznych. Chodzi raczej o rozłożenie akcentów albo jeszcze lepiej: o ukazanie dzieła Chrystusowego z nowego punktu widzenia.

Ewangelia Mateusza była mocno związana z Pismem Świętym ST. Jednym z głównych celów Mateusza było wykazanie, że Jezus wypehnia Pismo. Formuła „A stało się to wszystko, aby wypełniło się słowo powiedziane przez proroka..." powtarza się w jego Ewangelii jak refren. Wszystkich wyraźnych cytatów u Mt jest 41. Otóż z pewnością Rzymianin nie był zbytnio zainteresowany spełnieniem się 
proroctw powtarzanych $\mathrm{w}$ małym izraelskim narodzie leżącym gdzieś na końcu znanego mu świata. Już na pierwszy rzut oka widzimy, ze Marek bardzo wiele Mateuszowych cytatów ze ST opuszcza.

Tego rodzaju odejście od motywacji biblijnej w głoszeniu Ewangelii w środowisku pogańskim zauważamy porównując np. pierwsze kazanie św. Piotra do Żydów w Jerozolimie (Dz 2,14-36) i kazanie św. Pawła w Antiochii Pizydyjskiej (Dz 13,16-41) z kazaniem św. Pawła w Atenach (Dz 17,22-31). Św. Piotr trzy razy powołuje się na ST cytując $z$ niego aż 11 wierszy. Św. Paweł przemawiając w Antiochii Pizydyjskiej w synagodze cytuje ST siedem razy zaznaczając wyraźnie, że Bóg wyprowadził Izraelowi Zbawiciela z potomstwa Dawida zgodnie z obietnicą. Ale w przemówieniu do Greków w Atenach nie powołuje się ani jeden raz na ST i nic nie wspomina o obietnicach danych Żydom; tutaj kładzie akcent na to, że „Bóg wzywa teraz wszędzie i wszystkich ludzi do nawrócenia", a uwierzytelnieniem tego wezwania jest cud wskrzeszenia $\mathrm{z}$ martwych Jezusa (por. w. 31).

Zwracając się do pogan Kościół pierwotny musiał niewątpliwie zmienić koncepcję przepowiadania, tzn. tak sformułować swoje orędzie, aby ono odpowiadało oczekiwaniom pogan albo przynajmniej było bliższe ich sytuacji egzystencjalnej. Rzymianin nie mógł być zainteresowany realizacją obietnic Bożych danych Żydom, ale mogła go pociągnąć do Jezusa obietnica zbawienia dla każdego przez wiarę w Niego, mogła go pociągnąć prawda o objawieniu się Boga w Jezusie. Prawdopodobnie w przepowiadaniu Piotra, na pierwszy plan nie zostaje wysunięte spełnienie się Pisma w życiu, śmierci i zmartwychwstaniu Jezusa-Mesjasza, ale zostaje wysunięta prawda o synostwie Bożym Jezusa i o Jego zbawczej ingerencji na rzecz człowieka, a samo przepowiadanie staje się bardziej „dobrą nowiną” niż „nauką”. Właśnie ten nowy sposób przepowiadania Marek, sekretarz Piotra, miał prawdopodobnie ukazać w swoim dziele. Czyż nie wskazuje na to użycie przez Marka terminu „ewangelia"? W Ewangelii Mateusza znajduje się on tylko 4 razy, podczas gdy u Marka aż 8 razy. Zwróćmy uwagę na różnicę, jaka występuje $\mathrm{w}$ pierwszym sumarium działalności Jezusa w Galilei u Marka w stosunku do Mateusza. Pierwszy ewangelista pisze: „Odtąd począł Jezus nauczać i mówić: „Nawracajcie się, albowiem bliskie jest królestwo niebieskie" (Mt 4,17); natomiast Marek pisze: „(Jezus) Mówił: „Czas się wypełnił i bliskie jest królestwo Boże. Nawracajcie się i wierzcie w Ewangelię!” (Mk 1,15). Dodajmy, że termin Ewangelia u Łukasza występuje tylko dwa razy w Dz, w Ewangelii Jana w ogóle nie występuje, natomiast 69 razy 
w Listach św. Pawła, raz w Listach św. Piotra (1 P 4,17) i raz w Apokalipsie.

Być może też w przepowiadaniu Piotra w Rzymie do pogan na pierwsze miejsce, jeśli chodzi o motywy wiarygodności Ewangelii, wysuwają się nie teksty biblijne, ale cuda Jezusa. Byłoby to zupełnie uzasadnione. W każdym bądź razie nie można się dziwić, że Marek piszący dla pogan kładzie większy akcent na cuda niż na przepowiednie proroków. To skoncentrowanie się na cudach Jezusa nie jest więc, jak się często twierdzi, znakiem pierwotności tej Ewangelii i nie rozwiniętej jeszcze teologii, ale wynikiem zmiany koncepcji przepowiadania związanej ze zmianą audytorium.

Podkreślenie w przepowiadaniu tematu „dobrej nowiny” miało też ze swojej strony uzasadnienie biblijne; w ST znajduje się pięć proroctw o głoszeniu dobrej nowiny: w Iz 40,9; 52,$7 ; 60,6 ; 61,1$ oraz w Ps 95,3. Konieczność zmiany koncepcji przepowiadania kieruje zainteresowanie Marka - a może Piotra - do tych tekstów. Co jest przedmiotem ewangelii według tych proroctw?

Przedmiotem dobrej nowiny np.w Iz 40,1-11 jest przyjście Boga z wielką mocą dla zbawienia swojego ludu. Taka treść Ewangelii odpowiada nowym wymaganiom. Marek postanawia przeredagować Ewangelię Mateusza w świetle tego proroctwa. A zatem głównym tematem zwłaszcza w pierwszej części, do wyznania wiary Piotra (Mk 8,27-30), czyni przyjście Boga w Jezusie. Marek opowiadając o cudach Jezusa stara się przekonać czytelnika, że jest On pełnym mocy Synem Bożym. Na 111 perykop aż 43 ma jako temat tajemnicę Jezusa. Marek nie tylko umieszcza w swojej Ewangelii przede wszystkim wydarzenia mówiące o boskiej godności Jezusa, ale ponadto tak je opracowuje, aby zasugerować, że świadkowie życia Jezusa nie zdawali sobie sprawy z tego, kim On naprawdę był. $\mathrm{Np}$. z tekstu Ewangelii Mateusza usuwa te zdania, z których wynikałoby zrozumienie tajemnicy Jezusa przez apostołów; por.: Mk 4,13/Mt 13,16-17; Mk 6,45-52/Mt 14,33; Mk 8,29/Mt 16, 16.

Ewangelia Mateusza związana była ściśle z typologią wyjścia, z typologią drugiego Mojżesza, z założenia miała być nową, mesjańską Torą. ${ }^{9}$ Żydzi w czasach Chrystusa czekali na „Proroka jak Mojżesz", którego Bóg miał im dać zgodnie z obietnicą zapisaną w Pwt 18,15: „Pan, Bóg twój, wzbudzi ci proroka spośród braci twoich, podobnego do mnie. Jego będziesz słuchał”. Spodziewali się też nowego wyjścia - w tym wypadku wyjścia z niewoli rzymskiej, spodziewali sie wielkich wydarzeń na pustyni, cudów na rzecz Izraela. Pierwotna gmina w Jerozolimie jest przekonana, że proroctwo o „Proroku jak Mojżesz” spełnia się na Jezusie, jest przekonana, że działalność

${ }^{9} \mathrm{~A} . \mathrm{K}$ o w a l c z y k, Wplyw typologii oraz tekstów Starego Testamentu na redakcję Ewangelii św. Mateusza, Gdańsk 1993. 
Jezusa to nowe wyjście. Ale wyjście to nie polega na wyzwoleniu politycznym - jest ono wyjściem z niewoli grzechu. Mateusz pisząc o Jezusie dla Żydów wybiera z Jego z życia to, co Go upodobniało do Mojżesza: prześladowanie $\mathrm{w}$ dzieciństwie, moc czynienia cudów, ogłoszenie Prawa, brak wiary w narodzie wybranym w posłannictwo zesłanego przez Boga Przywódcy. Bierze on nawet pod uwagę to, ile razy autor natchniony wspomina o pewnych wydarzeniach $\mathrm{w}$ dziejach wyjścia - i tyle samo razy pisze o nich w swojej Ewangelii. Np. w relacji do dwukrotnego nakarmienia ludu na pustyni mięsem przepiórek pisze on o dwukrotnym rozmnożeniu chleba i ryb na pustyni; w relacji do działalności Mojżesza na czterech różnych szczytach górskich, pisze o czterokrotnym pobycie Jezusa na jakiejś górze; w relacji do dziesięciu zwycięstw Mojżesza nad poganami pisze o dziesięciu zwycięstwach Jezusa nad szatanem itd. Również tematyka kazań Jezusa jest $\mathrm{w}$ dużej mierze związana $\mathrm{z}$ tematyką zawartych w Pięcioksięgu przepisów. Najwyraźniej widać to w kazaniu na górze (Mt 5-7), które w dużej części jest po prostu interpretacją Dekalogu i innych nakazów i zakazów znajdujacych się w Kodeksie Synaickim, czyli w rozdz. 19-23 Ksiegi Wyjścia. W Ewangelii Mateusza Jezus jest zresztą nie tylko nowym Mojżeszem, ale także Nowym Jozuem - Jezus przez swoją mękę i zmartwychwstanie zdobywa królestwo niebieskie. Mateusz buduje strukturę swojego dzieła również $w$ relacji do opisu zdobycia ziemi obiecanej.

Marek niezupelnie uwalnia się od literackich schematów i założeń Ewangelii Mateusza, jednak koncepcja tej Ewangelii jako nowej Tory pozostającej w ścisłej relacji z Pięcioksięgiem nie odpowiada mu. Nowa koncepcja przepowiadania - koncepcja „Dobrej nowiny” o przyjściu na świat Syna Bożego w celu zbawienia człowieka domagała sie również nowego dzieła pisanego o Jezusie. Należało uczynić z niej bardziej Ewangelię - tak zresztą Marek nazywa swoje dzieło (por. 1,1) - należało skoncentrować uwagę czytelnika na nadprzyrodzonej mocy Jezusa, ograniczyć treść doktrynalną. Marek usuwa więc z Ewangelii Mateusza ewangelię dziecięctwa (Mt 1-2), zamazywała bowiem obraz przyjścia Boga pełnego mocy, oraz usuwa wiele pouczeń etycznych i przypowieści. Dlaczego usuwa całe kazanie na górze? Odpowiedzieć na to pytanie możemy po dogłębnej analizie poszczególnych jej perykop; przyczyny bedą różne zależne od treści perykopy, mianowicie: zbyt silne powiązanie $\mathrm{z}$ problemem prawa ST lub konieczność wyjaśnień ze względu na trudną treść danej perykopy. Na ten temat pisałem szerzej w artykule „Próba wyjaśnienia różnic w kompozycji $\mathrm{Mt}-\mathbf{M k}{ }^{10}$

Podsumowując te rozważania stwierdzamy, że Marek współpracownik apostoła Piotra w środowisku pogan w Rzymie, miał

10 „Studia Theologica Varsaviensia” 31/1 (1993) 77-116. 
kilka powodów, ażeby napisać drugą Ewangelię: pierwszy powód to zbyt ścisłe powiązanie Ewangelii Mateusza ze środowiskiem żydowskim i z tematyką żydowską, zbyt podkreślony w tej Ewangelii problem Prawa; drugi powód to zbyt mocne akcenty antyjudaistyczne w Ewangelii Mateusza; trzeci powód to dostosowanie Ewangelii pisanej do nowej koncepcji przepowiadania - według której należało kosztem pouczeń etycznych i analogii z Torą położyć większy nacisk na dobrą nowinę o Jezusie Synu Bożym - Zbawicielu człowieka.

Nie bez znaczenia w tym wypadku jest fakt, że Łukasz trzeci ewangelista, też piszący dla pogan, ukazuje obraz Jezusa-Zbawiciela jeszcze wyraźniej. Tylko u niego mamy termin Soter - Zbawiciel (2 razy) oraz soteria i soterion. A zatem Marek jest na linii rozwoju przepowiadania ujętego $\mathrm{w}$ tym aspekcie od Mateusza do Łukasza.

Gdañsk

Ks. ANDRZEJ KOWALCZYK

\section{Wojciech Słomski}

\section{EKUMENIZM W NOWYM TESTAMENCIE}

Ruch ekumeniczny zrodził się we współczesnym podzielonym chrześcijaństwie, w podzielonym Kościele Jezusa Chrystusa. W Nowy Przymierzu należy szukać korzeni tego współczesnego ekumenicznego cudu. Co więcej cały Nowy Testament jest jednym wielkim wołaniem o jedność uczniów Pańskich. Było ono przez wieki niezauważalne $i$ dlatego $z$ winy samych chrześcijan powstały w Kościele rozłamy trwające do czasów obecnych. Z winy samych chrześcijan narastała i utrwalała się niechęć i nawet nienawiść jednych do drugich, brak szacunku, tolerancji, fanatyzm religijny, prześladowania czy wojny religijne.

Rozłamy miały swój początek już w czasach apostolskich. Paweł w listach, napominal, prosił o zachowanie jedności; „Błagam was, bracia, w imię Pana naszego Jezusa Chrystusa, abyście wszyscy mówili to samo $i$ aby nie bylo wśród was rozłamów. Żyjcie w zgodzie, badźcie wszyscy tej samej myśli i tego samego ducha. Każdy z was mówi: ja jestem od Pawla, a ja od Apollosa; ja od Kefasa, a ja

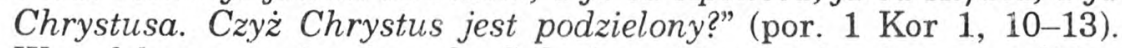
W podobnym tonie pisze do Galatów: „Wszyscy bowiem zostaliście 